\title{
PERFORMANCES OF HTLV SEROLOGICAL TESTS IN DIAGNOSING HTLV INFECTION IN HIGH-RISK POPULATION OF SÃO PAULO, BRAZIL
}

\author{
Fabrício JACOB(1), Elizabeth de los SANTOS-FORTUNA(1), Raymundo Soares AZEVEDO(2) \& Adele CATERINO-DE-ARAUJO(1)
}

\begin{abstract}
SUMMARY
Testing problems in diagnosing human T-lymphotropic virus (HTLV) infection, mostly HTLV-II, have been documented in HIV/AIDS patients. Since December 1998, the Immunology Department of Instituto Adolfo Lutz (IAL) offers HTLV-I/II serology to Public Health Units that attend HTLV high-risk individuals. Two thousand, three hundred and twelve serum samples: 1,393 from AIDS Reference Centers (Group I), and 919 from HTLV out-patient clinics (Group II) were sent to IAL for HTLV-I/II antibodies detection. The majority of them were screened by two enzyme immunoassays (EIAs), and confirmed by Western Blot (WB 2.4, Genelabs). Seven different EIA kits were employed during the period, and according to WB results, the best performance was obtained by EIAs that contain HTLV-I and HTLV-II viral lysates and rgp21 as antigens. Neither $1^{\text {st }}$ and $2^{\text {nd }}$, nor $3^{\text {rd }}$ generation EIA kits were $100 \%$ sensitive in detecting truly HTLV-I/II reactive samples. HTLV-I and HTLV-II prevalence rates of $3.3 \%$ and 2.5\% were detected in Group I, and of $9.6 \%$ and $3.6 \%$ in Group II, respectively. High percentages of HTLV-seroindeterminate WB sera were detected in both Groups. The algorithm testing to be employed in HTLV high-risk population from São Paulo, Brazil, needs the use of two EIA kits of different formats and compounds as screening, and because of high seroindeterminate WB, may be another confirmatory assay.
\end{abstract}

KEYWORDS: Human T-lymphotropic virus type I and II (HTLV-I and HTLV-II); Serology; Enzyme immunoassay (EIA); Diagnosis; Performance; High-risk population.

\section{INTRODUCTION}

Brazil has been pointed as the country with the highest absolute number of HTLV-I/II-seropositive individuals in the world, and shows heterogeneous distribution of HTLV-I and HTLV-II depending on the ethnic background of individuals and its geographic location ${ }^{4,12}$.

A variety of clinical conditions has been associated with HTLV-I, and more recently with HTLV-II, making the accurate diagnosis of such viruses important to prompt attend and counsel the HTLV-infected individuals ${ }^{12}$.

Although among endemic populations vertical and sexual transmission seems to be the most important means of virus transmission/acquisition, blood was considered a vehicle of HTLV-I/ II transmission mostly among intravenous drug users (IVDU), infected with HIV-1 ${ }^{2,3,5,6,9,12}$. In 1993, HTLV serology became mandatory in Blood Centers of Brazil, and more recently, the Ministry of Health recommended two algorithms to be used in Blood Donation Services and Public Health Laboratories of this country ${ }^{8}$. In Blood Centers, serum samples were screened for the presence of HTLV-I/II-specific antibodies using one enzyme immunoassay (EIA) which contains selected antigens for HTLV-I and HTLV-II. Reactive or indeterminate sera were re-tested in duplicate on the same EIA; samples that resulted seroreactive or seroindeterminate exclude its blood donation. Concerning Public Health Laboratories, after HTLV-I/II EIA screening, seroreactive samples were confirmed by immunofluorescence (IFA) or Western blot (WB) assays ${ }^{8}$.

Previous studies have shown serologic testing problems in diagnosing HTLV, mostly HTLV-II infection among HIV/AIDS patients from Brazil ${ }^{2-5,10}$, independently of the test algorithm employed, and the polymerase chain reaction (PCR) and IFA were suggested as HTLV confirmatory assays $\mathrm{s}^{3,5-7,10,12}$.

The Immunology Department of Instituto Adolfo Lutz offers HTLVI/II serology to Public Health Units since December 1998. Instituto Adolfo Lutz (IAL) is a Central Public Health Laboratory of São Paulo City, which is reference of several infectious diseases, including HIV/ AIDS. Its staff is composed by scientific researchers along with technical personal capable of doing, controlling, and analyzing routine procedures for diagnosis. Serological kits for routine purpose were acquired according to supply and demand or by convenience, and the test algorithm used for HTLV-I/II antibodies detection includes two EIAs of different formats and compounds as screening, and Western Blot (WB) as confirmatory test.

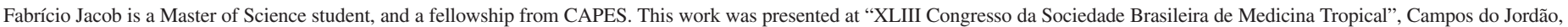
SP, Brasil, 2007.

Support: Instituto Adolfo Lutz (CTC \# 04/05).

(1) Seção de Imunologia, Instituto Adolfo Lutz, São Paulo, SP, Brasil.

(2) Departamento de Patologia, Faculdade de Medicina, Universidade de São Paulo, São Paulo, SP, Brasil.

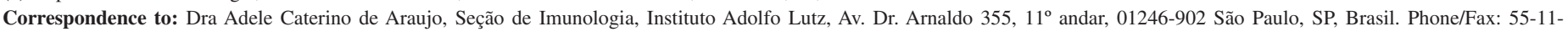
30682898. E-mail: caterino@ial.sp.gov.br 


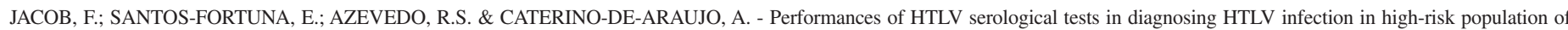
São Paulo, Brazil. Rev. Inst. Med. trop. S. Paulo, 49(6): 361-364, 2007.

The present study had the aim to analyze the results obtained from the HTLV-serological routine of IAL, showing the attended population, the diversity of available EIA kits and its performances according to WB confirmatory results, and the prevalence rates of HTLV-I and HTLVII antibodies in high-risk population from São Paulo, Brazil.

\section{MATERIALS AND METHODS}

From December 1998 to March 2006, 2,312 serum samples from São Paulo City and vicinity were sent to IAL for HTLV-I/II serology: $1,393(60.25 \%)$ came from AIDS Reference Centers (411 from females and 982 from males, Group I), and 919 (39.75\%) sera were from HTLV out-patient clinics (381 females and 539 males, Group II). The population aged 21 to 50 years with a peak of 31 to 40 years. Fourhundred fifty-five samples $(19.68 \%)$ were screened for the presence of HTLV-I/II specific antibodies by only one EIA kit, and 1,857 (80.32\%) were tested by two HTLV-I/II EIA kits. During the period, seven different EIA kits were employed, and the reactions were conducted according to manufacturer instructions. Serum samples that resulted OD/cutoff $\geq 1.0$ were considered reactive for HTLV-I/II antibodies. Sera that resulted reactive on at least one EIA, were submitted to WB test, and the results were interpreted according to the stringent criteria indicated by the manufacturer (WB HTLV 2.4, Genelabs ${ }^{\circledR}$ Diagnostics).

HTLV-I/II serological results were collected and analyzed using the Minitab Program (MINITAB ${ }^{\circledR}$ Release 14.1 (C) 1972-2003 Minitab Inc.). For the calculation of sensitivity, specificity, and efficiency it was considered only the positive or negative results on WB 2.4. To conduct the present study, ethical institutional approval was obtained.

\section{RESULTS}

After HTLV-I/II EIA screening, 461 sera that resulted reactive on at least one EIA were submitted to WB 2.4 assay: 94 out of 455 screened on one EIA, and 367 out of 1,857 tested on two EIAs. The results obtained on WB 2.4 of each Group as well the general results obtained were presented in Table 1. Antibodies to HTLV-I and HTLV-II were detected in both Groups, although HTLV-I was more prevalent among individuals of Group II. High percentages of HTLV-indeterminate WB results were observed in both Groups of individuals (Table 1).

Table 1

Prevalence rates of HTLV-I and HTLV-II antibodies in high-risk population of São Paulo according to EIA confirmed by WB 2.4

\begin{tabular}{|c|c|c|c|}
\hline \multirow[b]{2}{*}{ Results } & \multicolumn{3}{|c|}{ EIA } \\
\hline & $\begin{array}{c}\text { Group I } \\
\text { n (\%) }\end{array}$ & $\begin{array}{c}\text { Group II } \\
\mathrm{n}(\%)\end{array}$ & $\begin{array}{l}\text { Total } \\
\mathrm{n}(\%)\end{array}$ \\
\hline HTLV-I & $46(3.30)$ & $88(9.58)$ & $134(5.80)$ \\
\hline HTLV-I/II & $1(0.07)$ & $2(0.22)$ & $3(0.13)$ \\
\hline HTLV-II & $35(2.51)$ & 33 (3.59) & $68(2.94)$ \\
\hline HTLV & $1(0.07)$ & $13(1.41)$ & $14(0.61)$ \\
\hline Indeterminate & $75(5.38)$ & $88(9.58)$ & 163 (7.05) \\
\hline Negative & $1,235(88.66)$ & $695(75.63)$ & $1,930(83.48)$ \\
\hline Total & $1,393(100.00)$ & $919(100.00)$ & $2,312(100.00)$ \\
\hline
\end{tabular}

Group I: sera from individuals attended at AIDS Reference Centers of São Paulo. Group II: sera from individuals seen at HTLV out-patients clinics of São Paulo.
Using WB 2.4 as the gold standard for HTLV-seroreactive samples, the sensitivity, specificity, and efficiency of EIA kits were calculated and presented in Table 2. The overall analysis of EIAs disclosed the best performance of the EIA kit which employed HTLV-I and -II viral lysates plus rgp21 (Vironostika HTLV-I/II, BioMerieux**).

Table 2

Sensitivity, specificity, and efficiency of the HTLV-I/II EIA kits in detecting HTLV-specific antibodies in relation to WB 2.4, on high-risk population of São Paulo

\begin{tabular}{rccc}
\hline & $\begin{array}{c}\text { Sensitivity } \\
(\%)\end{array}$ & $\begin{array}{c}\text { Specificity } \\
(\%)\end{array}$ & $\begin{array}{c}\text { Efficiency } \\
(\%)\end{array}$ \\
\hline $\mathbf{1}^{\text {st }}$ EIA set $(\mathbf{n}=\mathbf{1 , 0 7 1})$ & & & \\
$\mathbf{V}^{*}(\mathbf{n}=\mathbf{1 9 4})$ & 71.4 & 100.0 & 78.9 \\
$\mathbf{H B}(\mathbf{n}=\mathbf{1 8 2})$ & 80.9 & 33.3 & 70.4 \\
$\mathbf{P}(\mathbf{n}=\mathbf{6 9 5})$ & 98.4 & 44.4 & 82.4 \\
$\mathbf{2}^{\text {nd }} \mathbf{E I A}$ set $(\mathbf{n}=\mathbf{9 2 5})$ & & & \\
$\mathbf{V}^{* *(\mathbf{n}=\mathbf{6 6 0})}$ & 95.8 & 70.0 & 90.2 \\
$\mathbf{H E}(\mathbf{n}=\mathbf{2 6 5})$ & 90.9 & 83.3 & 86.9 \\
$\mathbf{3}^{\text {rd }} \mathbf{E I A} \mathbf{s e t}(\mathbf{n}=\mathbf{2 , 1 7 3})$ & & & \\
$\mathbf{O}(\mathbf{n}=\mathbf{4 5 4})$ & 94.4 & 46.7 & 80.4 \\
$\mathbf{M}(\mathbf{n}=\mathbf{1 , 7 1 9})$ & 98.2 & 42.6 & 83.7 \\
\hline
\end{tabular}

n: number of serum samples analyzed; $1^{\text {st }}$ EIA set: EIA kits that use HTLV-I/II viral lysates as antigen (Hemobio HTLV-I/II HBK 424, EMBRABIO; Platelia ${ }^{\circledR}$ HTLV-I New, Bio-Rad; Vironostika ${ }^{\circledR}$ HTLV-I/II, Organon Teknika Corp.*); $2^{\text {nd }}$ EIA set: EIA kits that employ HTLV-I/II viral lysates plus recombinant antigens (Hemagen ${ }^{\circledast}$ HTLV-I + HTLV-II, Hemagen Diagnósticos Com. Ltda; Vironostika HTLV-I/II, BioMerieux**); $3^{\text {rd }}$ EIA set: EIA kits that contain HTLV-I/II recombinant antigens/synthetic peptides as antigens (Murex HTLV-I+II, Murex Biotech; Ortho ${ }^{\circledR}$ HTLV-I/HTLV-II, Ortho Clinical Diagnostics Inc.).

As shown in Table 3, 19 (11.45\%) samples that resulted discordant on EIA analysis, confirmed HTLV-seropositivity on WB 2.4, and pointed out the need of using two EIAs for confirming HTLV infection in high risk population of São Paulo. Indeed, this finding stated that EIA kits which use recombinant proteins/synthetic peptides as antigen are more sensitive than the other kits (see column 1 in Table 3); on the other hand, EIA kits that employ viral lysates plus recombinant antigens were more specific (see column 3 in Table 3 ).

\section{DISCUSSION}

The present study disclosed the performance of HTLV serological tests used in the routine procedure of IAL, a Public Health Laboratory from São Paulo, Brazil, and pointed some conditions that could affect the reliability of HTLV serological diagnosis in high-risk population of this geographic area. Initially, the HTLV EIA kits employed on serodiagnosis of HTLV-I/II were obtained by supply and convenience, and during the period analyzed, seven different kits were used as screening. Some EIAs changed manufacturer, others disappeared from commerce, and finally some EIA kits improved antigen composition adding recombinant proteins and/or synthetic peptides from HTLV-I and -II (data not shown). Although these changes, neither $1^{\text {st }}$ and $2^{\text {nd }}$ nor $3^{\text {rd }}$ generation EIA kits were $100 \%$ sensitive in detecting HTLV-I/ II antibodies in such population. As shown in Table 3, $11.45 \%$ of sera that resulted discordant on EIAs resulted WB 2.4 positive. Thus, the use of only one EIA kit as screening as recommended by the Ministry 


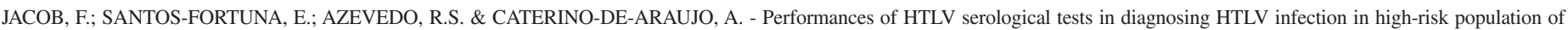
São Paulo, Brazil. Rev. Inst. Med. trop. S. Paulo, 49(6): 361-364, 2007.

Table 3

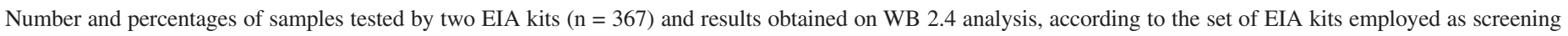

\begin{tabular}{|c|c|c|c|c|}
\hline \multirow[t]{2}{*}{ EIA set (results) } & \multicolumn{4}{|c|}{ WB 2.4} \\
\hline & $\begin{array}{c}\text { Positive } \\
\text { n }(\%)\end{array}$ & $\begin{array}{c}\text { Indeterminate } \\
\mathrm{n}(\%)\end{array}$ & $\begin{array}{c}\text { Negative } \\
\mathrm{n}(\%)\end{array}$ & $\begin{array}{l}\text { Total } \\
\mathrm{n}(\%)\end{array}$ \\
\hline Discordant & $19(11.45)$ & $93(56.02)$ & $54(32.53)$ & $166(100.00)$ \\
\hline $1^{\text {st }}(-)$ vs $3^{\text {rd }}(+)$ & $9(18.00)$ & $24(48.00)$ & $17(34.00)$ & $50(100.00)$ \\
\hline $1^{\text {st }}(+)$ vs $3^{\text {rd }}(-)$ & $3(5.45)$ & $35(63.65)$ & $17(30.91)$ & $55(100.00)$ \\
\hline $2^{\text {nd }}(-)$ vs $3^{\text {rd }}(+)$ & $5(15.15)$ & $13(39.39)$ & $15(45.45)$ & $33(100.00)$ \\
\hline $2^{\text {nd }}(+)$ vs $3^{\text {rd }}(-)$ & $2(7.14)$ & $21(75.00)$ & $5(17.86)$ & $28(100.00)$ \\
\hline Concordant $(+)$ & $153(76.12)$ & $44(21.89)$ & $4(1.99)$ & $201(100.00)$ \\
\hline
\end{tabular}

WB: WB HTLV 2.4, Genelabs ${ }^{\circledR}$ Diagnostics.

of Health of Brazil ${ }^{8}$, may account for the lacking of truly HTLV-I/IIinfected patients. In accordance with this hypotheses, several years ago a group of researchers from San Francisco, California, described HTLV-false-negative EIA results on plasma samples from 50 injection drug users (IDU) HTLV-II-infected. Although these problem specimens resulted WB-indeterminate on two commercial WB kits, they were confirmed as HTLV-II-infected by IFA and PCR ${ }^{7}$. That work and the present study make possible to speculate that during the period of which only one EIA screening was employed in high-risk population from São Paulo, some HTLV-infected patients could be missing. We do not know the risk factor for acquiring retroviruses of patients, but since sera from Group I came from AIDS Reference Centers, surely IVDU would be included. Indeed, we may not exclude the same risk factor among some patients from Group II.

At present, although $3^{\text {rd }}$ generation EIA kits showed high sensitivity in detecting HTLV-I/II positive sera, kits of $2^{\text {nd }}$ generation showed the best performance when used on high-risk population from São Paulo (Tables 2 and 3); this result contrast with a previous study of HIV/ AIDS patients conducted by some of us in another region of Brazil, (Londrina, Paraná) of which $3^{\text {rd }}$ generation EIA kit showed the best result on HTLV-I/II serological screening ${ }^{10}$. On the other hand, in agreement with the present results, several years ago, an EIA kit that employed HTLV-I and HTLV-II viral lysates (ELISA HTLV-I/II, EMBRABIO, BR) presented the best results on high-risk population of São Paulo, Brazil ${ }^{5}$. Interestingly, both studies employed the PCR for confirming the presence of HTLV-I and HTLV-II provirus in blood, strategy that could not be used in the present study, since the fluid sent for routine purpose was sera, and no cells were available, which were necessary for searching HTLV provirus in blood ${ }^{12}$.

The source of missing HTLV-seropositive samples in high-risk population may be the immunosuppression and/or seroconversion period of which these patients were undergone. In fact, previous studies showed that HIV/HTLV-II co-infected patients were enable to mount and/or maintain an appropriate level of HTLV-II antibodies, particularly in advanced stages of HIV infection ${ }^{1,12,14}$. We do not know the real immunological status of patients but we could speculate immunosuppression as the cause of serological lack, mostly in patients of Group I. Of note, we could not discard the same immunological suppression among patients from Group II, since their HIV status was unknown.
Interestingly, patients from Group II presented higher proportion of HTLV-I-seropositive results (Column 2, Table1), and this finding could be related to clinical manifestations associated to HTLV-I seen at HTLV out-patient clinics, such as adult T cell leukemia/lymphoma (ATL), and tropical spastic paraparesis or HTLV-associated myelopathy (TSP/HAM) ${ }^{12}$. Although medical requests for HTLV-I/II serology do not contain clinical and epidemiological data of such patients, in several ocasions the serology requests were signed by hematologists and neurologists. Of note, TSP/HAM simile diagnosis was recently reported in São Paulo, Brazil, in HIV/HTLV-II co-infected patients ${ }^{11}$, and although HTLV-II solely were associated with an increased incidence of pneumonia and bronchitis, arthritis, and few cases of cutaneous lymphoma, when associated with HIV may alter the levels of CD4+ and CD8+ lymphocytes, and under antiretroviral therapy may increase HTLV-II proviral load ${ }^{13}$.

In conclusion, the present study emphasizes the need of two EIAs of diverse antigens and formats to be used in high risk population from São Paulo, Brazil, and confirms high number of HTLVseroindeterminate samples which will be analyzed apart.

\section{RESUMO}

\section{Desempenho de testes sorológicos para o diagnóstico de infecção por HTLV em população de alto-risco de São Paulo, Brasil}

Problemas nos testes diagnósticos de infecção pelos vírus linfotrópicos de células T humanas (HTLV), principalmente HTLV-II, têm sido observados em pacientes com HIV/Aids. Desde Dezembro de 1998, a Seção de Imunologia do Instituto Adolfo Lutz (IAL) oferece a sorologia para HTLV-I/II para Serviços de Saúde Pública que atendem populações consideradas de risco para esta infecção. Duas mil trezentas e doze amostras de soro: 1.393 de Centros de Referência em Aids (Grupo I) e 919 de Clínicas de Especialidade em HTLV (Grupo II) foram encaminhadas para o IAL para a pesquisa de anticorpos antiHTLV-I/II. A maioria delas foram testadas por dois ensaios imunoenzimáticos (EIAs) e confirmadas por Western Blot (WB 2.4, Genelabs). Sete kits diferentes de EIAs foram empregados durante $\mathrm{O}$ período e de acordo com os resultados do WB a melhor performance foi obtida com os EIAs que continham lisado viral dos HTLV-I e -II e a rgp21 como antígenos. Nenhum kit de EIA de $1^{\mathrm{a}}, 2^{\mathrm{a}}$ ou $3^{\mathrm{a}}$ geração foi $100 \%$ sensível para detectar todas as amostras verdadeiramente HTLVI/II reagentes. A prevalência de HTLV-I e HTLV-II, respectivamente, 
foi de $3,3 \%$ e 2,5\% no Grupo I e de $9,6 \%$ e 3,6\% no Grupo II. Em ambos os Grupos, foram detectadas altas percentagens de soros com padrão indeterminado no WB. O algoritmo de testes sorológicos para ser usado em população de alto risco para HTLV de São Paulo, Brasil, necessita de dois kits EIAs de princípios e composição diferentes para a triagem sorológica e, pelo elevado número de WB indeterminado, talvez de um outro teste confirmatório.

\section{ACKNOWLEDGMENTS}

The authors thank Mirthes Ueda for text revision.

\section{REFERENCES}

1. BASSANI, S.; TORO, C.; JIMÉNEZ, V.; RODÉS, B. \& SORIANO, V. - Can the level of immunosuppression in human immunodeficiency virus-infected patients affect the reliability of human T-cell lymphotropic virus type 2 serological diagnosis? Clin. Vacc. Immunol., 13: 160-161, 2006.

2. CASSEB, J.; CATERINO-DE-ARAUJO, A.; HONG, M.A. et al. - Prevalence of HTLVI and HTLV-II infections among HIV-1-infected asymptomatic individuals in São Paulo, Brazil. Rev. Inst. Med. trop. S. Paulo, 39: 213-215, 1997.

3. CASSEB, J.; SOUZA, T.; PIERRE-LIMA, M.T. et al. - Testing problems in diagnosing HTLV infection among intravenous drug users with AIDS in São Paulo city, Brazil. AIDS Res. hum. Retrovir., 13: 1639-1641, 1997.

4. CATAlAn-SOARES, B.; CARneiro-PRoietti, A.B.; PROIETTI, F.A. \& Interdisciplinary HTLV Research Group - Heterogeneous geographic distribution of human T-cell lymphotropic viruses I and II (HTLV-I/II): serological screening prevalence rates in blood donors from large urban areas in Brazil. Cadern. Saúde públ. (Rio de J.), 21: 926-931, 2005.

5. CATERINO-DE-ARAUJO, A.; SANTOS-FORTUNA, E.; MELEIRO, M.C.Z. et al. Sensitivity of two ELISA tests in relation to Western blot in detecting HTLV-I and HTLV-II infection among HIV-1-infected patients from São Paulo, Brazil. Diagn. Microbiol. infect. Dis., 30: 173-182, 1998.

6. DE-ARAUJO, A.C.; CASSEB, J.S.R.; NEITZERT, E. et al. - HTLV-I and HTLV-II infections among HIV-1 seropositive patients in São Paulo, Brazil. Europ. J. Epidem., 10: 165-171, 1994.
7. GALLO, D.; DIGGS, J.L. \& HANSON, C.V. - Evaluation of two commercial human Tcell lymphotropic virus Western blot (immunoblot) kits with problem specimens. J. clin. Microbiol., 32: 2046-2049, 1994.

8. HTLV-I/II - Triagem e diagnóstico sorológico em unidades hemoterápicas e laboratórios de saúde pública. Brasília, Ministério da Saúde; Coordenação Nacional de Doenças Sexualmente Transmissíveis e Aids, 1998. (II, Série TELELAB)

9. MORIMOTO, H.K.; CATERINO-DE-ARAUJO, A.; MORIMOTO, A.A. et al. Seroprevalence and risk factors for human T-cell lymphotropic virus type 1 and 2 infection in human immunodeficiency virus (HIV)-infected patients attending AIDS Referral Center Health Units in Londrina and other communities in Paraná, Brazil. AIDS Res. hum. Retrovir., 21: 256-262, 2005

10. MORIMOTO, H.K.; MORIMOTO, A.A.; REICHE, E.M.V. et al. - Difficulties in the diagnosis of HTLV-2 infection in HIV/AIDS patients from Brazil. Comparative performances of serologic and molecular assays, and detection of HTLV-2b subtype. Rev. Inst. Med. trop. S. Paulo, 49: 225-230, 2007.

11. POSADA-VERGARA, M.P.; MONTANHEIRO, P.; FUKUMORI, L.M.I. et al. - Clinical and epidemiological aspects of HTLV-II infection in São Paulo, Brazil: presence of tropical spastic paraparesis/HTLV-associated myelopathy (TSP/HAM) simile diagnosis in HIV-1-co-infected subjects. Rev. Inst. Med. trop. S. Paulo, 48: 207$210,2006$.

12. PROIETTI, A.B.F.C. - HTLV. 4. ed. Belo Horizonte, Fundação Centro de Hematologia e Hemoterapia de Minas Gerais, 2006. (Cadernos Hemominas, v. XIII).

13. ROUCOUX, D.F. \& MURPHY, E.L. - The epidemiology and disease outcomes of human T-lymphotropic virus type II. AIDS Rev., 6: 144-154, 2004.

14. ZEHENDER, G.; DE MADDALENA, C.; GIANOTTO, M. et al. - High prevalence of false-negative anti-HTLV type I/II enzyme-linked immunosorbent assay results in HIV type 1-positive patients. AIDS Res. hum. Retrovir., 13: 1141-1146, 1997.

Received: 27 March 2007

Accepted: 27 June 2007 